\title{
研究報文
}

\section{ギニアグラスとクロタラリアの混作によるバイオマスと 土壤窒素動態への影響}

\author{
岩崎 明* · 小松崎将一 ** \\ *茨城大学大学院農学研究科, **茨城大学農学部附属フィールドサイエンス教育研究センター
}

Effects of Biculture of Guinea Grass (Panicum maximum Jacq.)

and Crotalaria (Crotalaria spectabilis Roth.) on Biomass Production and Soil Nitrogen Dynamics

\author{
Akira IwASAKI* and Masakazu KomatsuZAKI** \\ *Graduate school of Agriculture, Ibaraki university \\ **Center for Field Science Reserch and Education, Ibaraki University
}

\begin{abstract}
夏作カバークロップとしてイネ科やマメ科の作物が単独に用いられる場面が多いが，これらの 混作による効果はほとんど検討されていない. 本研究は茨城大学農学部附属フィールドサイエン ス教育研究センター内戒場において, 夏作カバークロップの混作を行いバイオマス生産と窒素溶 脱への効果の比較を行った．試験区はギニアグラス (Panicum maximum Jacq. 品種：ナツカゼ) とクロタラリア・スペクタビリス（Crotalaria spectabilis Roth. 品種：ネマクリーン）をそれぞれ の慣行の播種量を 100 として, ギニアグラス：クロタラリアの比率を変え設計を行った，処理区 は「100：0 (ギニアグラス単作区) $」 \cdot 「 75 ： 25 」 \cdot 「 50: 50 」 \cdot\lceil 25: 75 」 \cdot\lceil 0 ： 100$ (クロタラリア 単作区) 」·「0:0 (裸地区) 」の 6 処理を 3 反復とし乱塊法により設置した。 2016 年はカバークロッ プの地上部バイオマスや $\mathrm{C} / \mathrm{N}$ 比，地上部炭素含有量はギニアグラス単作区で最も高くなり，混 作ではやや低下した，2017 年ではカバークロップの地上部バイオマスはギニアグラス単作区と混 作区の $75 ： 25$ 区は同等であり $\mathrm{C} / \mathrm{N}$ 比は単作区より混作で低下することが認められた。また土壤 硝酸態窒素濃度において, 両年ともにカバークロップの作付により有意な減少が認められた。 2 年間の結果から, 夏作カバークロップの混作により単作に比べて同等の戋場に還元できるバイオ マス生産量を確保し， かつ $\mathrm{C} / \mathrm{N}$ 比を低減させて，良質な有機物供給が可能であることが明らか となった。
\end{abstract}

キーワード : ギニアグラス, クロタラリア, 混作, 窒素溶脱

\section{1. 緒言}

我が国では平成 23 年度から, 環境保全に効果 の高い営農活動に対して支援を行う環境保全型

2017 年 11 月 19 日受付

2018 年 2 月 9 日受理

Corresponding author

小松㟝将一 Masakazu KomatsuZAKI

干 300-0393 茨城県阿見町中央 3-21-1 茨城大学農学部 附属フィールドサイエンス教育研究センター

Center for Field Science Research \& Education, 3-21-1

Chuo, Ami-machi, Inashiki-gun, Ibaraki-ken, Japan

E-mail : masakazu.komatsuzaki.fsc@vc.ibaraki.ac.jp
農業直接支払交付金の交付が実施されており，力 バークロップの利用による取り組みが広がってい る。交付金の対象となる実施面積は，平成 28 年 度で 84,566 haであり, うちカバークロップの利 用によるものはその 2 割の 16,772 ha を占め増加 傾向にある(農林水産省 2017). このようにカバー クロップの利用は国や地方で導入が進められてお り，各自治体もカバークロップの利用マニュアル などを作成し，推進を図っている．

現在利用されているカバークロップの多くは牧 草・飼料作物として利用されていたものが多く, 
主にイネ科とマメ科植物が利用されている。カ バークロップは土䁃浸食防止, 緑肥, 杂隹草抑制, 線虫防除, 土壤物理性改善, 塩類集積除去など多 面的な機能を有している（小松㟝 2004）。このよ うにカバークロップの効果は多岐にわたるが，こ の中で代表的な機能としては窒素循環の改善があ る.とくに, マメ科のカバークロップ利用によ る後作物への養分供給については, トゥモロコ シ (Komatsuzaki 2002), トマト (Sugihara et al. 2013; 2016)，イネ (Asagi and Ueno 2009 ：小松㟝 2009), コムギ（平田ら 2017）の栽培に扔いて肥 料投入量を慣行の半分から 3 分の 1 に減少できる ことを明らかにしている。

カバークロップ利用による土壤有機物供給にお いて特筆すべき点は, カバークロップバイオマス による有機物供給とカバークロップが土壤残留養 分を吸収することで養分溶脱防止機能につながる 点である。土壤中に残留している養分は裸地条件 であると無機化が有機化を上回り，一部は循環す る一方で，降雨などによって土畩水と一緒に下方 に溶脱してしまうリスクが高い（小川2000）。特 に露地野菜栽培などでは化学肥料投入量が作物吸 収量に比べて多い傾向にあり，主作物が吸収しな かった残存養分が溶脱や表面流去し環境負荷とな る場合がある（大橋・俣野 2003）。これらの後作 においてカバークロップを作付することで，植 物による窒素吸収を促し, 溶脱抑制につながる

(Holderbaum et al. 1990 ; Kuo et al. 1996, Sainju et al. 1998). Abdul-Baki et al. (1997) および糟谷ら （2010）はブロッコリーやキャベッなどの主作物 の前作に緑肥を導入し，すき込むことで地力を維 持し, 後作物の増収や減肥につなげられることを 報告している.

カバークロップは導入される作付体系に応じて 夏作物と冬作物が用いられる。目て本では主作物が 夏作として組み込まれることが多いためカバーク ロップの利用は冬作カバークロップが多くの割合 を占める。これに対し，夏作カバークロップの利 用は冬作に比べ少なく研究も限られる。しかし, 夏季の高温多雨の気候は土壤中の有機物分解や土 壤養分の溶脱促進が危惧され，夏作カバークロッ プを利用し，環境保全と作物生産を両立すること が望まれる。

また，夏作カバークロップにおいては，線虫対 抗作物となるものも多く, 植物寄生性線虫抑制,
有機物供給および溶脱防止などの総合的な効果が 期待できる (水久保 2005)。 とくに, 大林ら (1989) や北上ら（1992）によるとギニアグラスやクロタ ラリアなどの夏作カバークロップでは植物寄生性 線虫の密度を抑制することが報告されており環境 保全型農業では農薬などの代替資材としても期待 される。

夏作カバークロップのなかには, ギニアグラス やソルガムなど $\mathrm{C}_{4}$ 植物が含まれており, 夏季の 強光下で効率的な光合成を行うため, 多量のバイ オマス生産が期待される. クロタラリアやセスバ ニアなどは熱帯原産のマメ科カバークロップであ りこれらは深根性で養分吸収量も多く, 根粒菌と の共生窒素固定により夏場に旺盛に生育し, すき 込み有機物量も多い（大門 2017）。一般にイネ科 のカバークロップは高い炭素固定能を有し多量の バイオマス生産が期待されるが, $\mathrm{C} / \mathrm{N}$ 比が高い 傾向にある. カバークロップの $\mathrm{C} / \mathrm{N}$ 比はすきこ まれた後の土壤中の分解速度に影響し, 高 $\mathrm{C} / \mathrm{N}$ 比のカバークロップは分解が遅いことや後作で窒 素飢餓を引き起こすリスクがある。これに対し， クロタラリアなどのマメ科のカバークロップは根 粒菌との共生関倸により窒素固定を行い, 低い $\mathrm{C} / \mathrm{N}$ 比のバイオマス生産が期待できる.

このため, イネ科とマメ科の混作によってカ バークロップの機能向上が期待される. 冬作カ バークロップの混作については比較的多く報告さ れており, イネ科作物とマメ科作物の生理的・形 態的な違いに基づく養分と光の相補的な利用に よって, 地上部バイオマス量や養分吸収量が増 大する効果が得られる (樽井ら 2011). さらに, イネ科とマメ科の混作によってマメ科作物由来 窒素がイネ科作物に供給されるという報告もあ る (Xiao et al. 2004 ; Rasmussen et al. 2007).こ れにより, 混作によってイネ科の高 $\mathrm{C} / \mathrm{N}$ 比に起 因する窒素飢餓のリスクを回避できる可能性があ る.

これらの混作の効果は夏作カバークロップにつ いても期待されるが, 夏作カバークロップの混作 による研究事例はほとんどみられない.このよう な背景から, 本研究では夏作カバークロップの更 なる利用拡大のために, 夏作カバークロップの単 作と混作の比較研究を行った。 ここでは, 夏作力 バークロップの混作による地上部バイオマス, 窒 素吸収および $\mathrm{C} / \mathrm{N}$ 比への影響と土畩窒素の動態 
について報告する．

\section{2. 材料および方法}

1）試験設計及び圃場管理

試験は茨城大学農学部附属フィールドサイエン ス教育研究センター内の洪積台地畑（土性：CL, $\mathrm{LiC})$ で 2016 年 6 月から 8 月（前作：コマツナ などの露地野菜), 2017 年 6 月から 9 月（前作： タマネギ）に実施した，施肥は両年ともに無施肥 で行った。

2016 年は $3 \mathrm{~m} \times 8 \mathrm{~m}$ を 1 区画とし，ギニアグ ラス (Panicum maximum Jacq. 品種：カネコ種 苗, ナツカゼ）とクロタラリア・スペクタビリス (Crotalaria spectabilis Roth. 品種：カネコ種苗，ネ マクリーン）を供試した。慣行の播種量をギニ アグラス（コート種子）は $3 \mathrm{~kg} / 10 \mathrm{a}$, クロタラ リアは $6 \mathrm{~kg} / 10$ a を 100 として, それぞれの播種 比率を 0〜100で表現した。すなわち，単作区を $\lceil 100 ： 0$ (ギニアグラス単作区) 」・「0：100（クロ タラリア単作区)」とした。また，混作区は播種 比率を変え $\lceil 75: 25\rfloor,\lceil 50: 50 」,\lceil 25: 75 」 と し$, 対照区として「0：0 (裸地区)」の 6 処理を 3 反 復とし乱塊法により設置した。

2016 年 6 月 3 日に圃場をロータリを用いて深 さ $15 \mathrm{~cm}$ で耕した。同年 6 月 6 日にカバークロッ プ種子を散播した。裸地区は 2 週に 1 度手取り除 草を行った。しかし，裸地区を含め全ての処理区 にメヒシバ (Digitaria ciliaris Koeler) などの雑草 の混入が確認された。

2017 年は, $3 \mathrm{~m} \times 3 \mathrm{~m}$ を 1 区画とした。標準播 種量はギニアグラスでは $2 \mathrm{~kg} / 10 \mathrm{a}$, クロタラリ アでは $5 \mathrm{~kg} / 10 \mathrm{a}$ とした。 2017 年 6 月 27 日に圃 場を前年と同様に耕した。 6 月 29 日に条間 $15 \mathrm{~cm}$ で条播した。すべての処理区において条間の徹底 除草を行った。

\section{2）カバークロップのサンプリングと分析}

カバークロップのサンプリングは, 2016 年 8 月 4 日（播種後 60 日目）に地上部を $0.25 \mathrm{~m}^{2}(0.5$ $\mathrm{m} \times 0.5 \mathrm{~m})$ のコドラートを用いて区画ごとに涧 り取った。また，翌年の 2017 年 9 月 3 日（播種 後 67 日目）に地上部 $3 \mathrm{~m}^{2}$ を区画ごとに刈り取っ た。両年ともに刈取後のサンプルは生重量を測定 後, その一部を作物乾燥用オーブンにより $60^{\circ} \mathrm{C}$ で 72 時間乾燥し乾物率を測定しバイオマスを算
出した。また，相対収量（RY： relative yield）は 以下により算出した.

$$
\begin{aligned}
& R Y_{G}=\frac{Y_{M G}}{Y_{S G}} \\
& R Y_{C}=\frac{Y_{M C}}{Y_{S C}} \\
& R Y_{T}=R Y_{G}+R Y_{C}
\end{aligned}
$$

$R Y_{G}:$ ギニアグラスの相対収量

$Y_{M G}:$ 混作区のギニアグラスのバイオマス

$Y_{S G}:$ 単作区のギニアグラスのバイオマス

$R Y_{C}$ : クロタラリアの相対収量

$Y_{M C}:$ 混作区のクロタラリアのバイオマス

$Y_{S C}$ : 単作区のクロタラリアのバイオマス

$R Y_{T}$ : 合計相対収量

さらにサンプルを乾燥・粉砕後, 炭素および 窒素含有率について炭素・窒素自動測定装置 （J-Science Lab Co. LTD. 製JM3000CN）で測定した.

3）土壤無機態窒素のサンプリングと分析

2016 年 6 月 10 日（播種 4 日後）と 8 月 6 日 (刈取 2 日後), 2017 年 7 月 4 日（播種 5 日後) と 9 月 6 日 (刈取 3 日後) に検土杖（大起理化工 業製 DIK-1640）を用いて 0-30 cm, 30-60 cm, 60-90 cm の3 層に分けて土壤を採取した。 それ ぞれの区画ごとに 2 箇所採取し，それらを混和し た。採取した土壤は湿土 $5 \mathrm{~g}$ を $1 \mathrm{~mol} \mathrm{~L}^{-1}$ の塩化力 リウム $40 \mathrm{ml}$ で抽出後, 土壤 $1 \mathrm{~kg}$ 当たりの硝酸 態窒素濃度とアンモニア態窒素濃度を土壤・作物 体総合分析機（島津製作所製，SPCA-6210）で測 定した。

\section{4) 統計解析}

得られた結果は統計ソフト Stat View（SAS Institute Inc.) を用いて Tukey-Kramer 法による 多重検定を行った。

\section{3. 結果}

1）カバークロップ地上部バイオマス

カバークロップの生育期間中の積算降水量は 2016 年では $171.5 \mathrm{~mm}, 2017$ 年では $243.0 \mathrm{~mm}$ で あり 2017 年で高かったが, 両年とも過去 30 年間 の平年值と比較して少ない降水量であった（図 1 ). とくに，2016 年は 7 月上・下旬と 8 月上旬の降 水量が平年值と比較して著しく低かった。 2017 

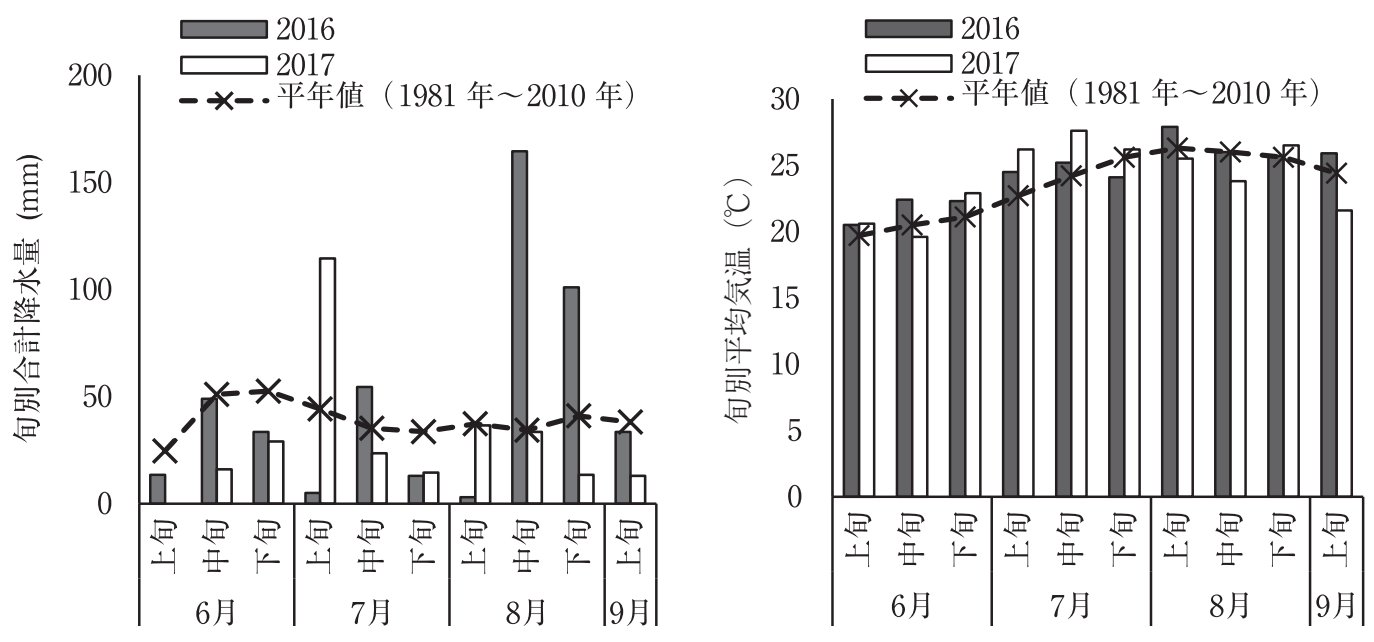

図 1 カバークロップ生育期間中の旬別合計降水量と旬別平均気温 アメダス土浦観測所データより作成 (気象庁).

表 1 ギニアグラスのバイオマス及び成分 (2016 年 8 月, 2017 年 9 月)

\begin{tabular}{|c|c|c|c|c|c|c|c|}
\hline & & \multicolumn{6}{|c|}{ ギニアグラス地上部 } \\
\hline \multicolumn{2}{|c|}{ 処理区 } & $\begin{array}{c}\text { バイオマス } \\
\text { (DW-kg/10 a) }\end{array}$ & $R Y_{G}$ & $\begin{array}{c}\mathrm{C} \text { 含有率 } \\
(\%)\end{array}$ & $\begin{array}{c}\mathrm{N} \text { 含有率 } \\
(\%)\end{array}$ & $\begin{array}{l}\text { C 含有量 } \\
(\mathrm{kg} / 10 \mathrm{a})\end{array}$ & $\mathrm{C} / \mathrm{N}$ 比 \\
\hline \multirow{5}{*}{2016} & $100: 0$ & $763 \pm 39 \mathrm{a}$ & 1.00 & $42.9 \pm 0.3$ & $1.8 \pm 0.0 \mathrm{~b}$ & $327 \pm 16.8 \mathrm{a}$ & $23.7 \pm 0.6 \mathrm{a}$ \\
\hline & $75: 25$ & $483 \pm 46 b$ & 0.63 & $42.6 \pm 0.2$ & $2.5 \pm 0.1 \mathrm{a}$ & $206 \pm 20.4 b$ & $17.0 \pm 0.6 \mathrm{~b}$ \\
\hline & $50: 50$ & $411 \pm 60 \mathrm{~b}$ & 0.54 & $43.0 \pm 0.4$ & $2.2 \pm 0.2 \mathrm{ab}$ & $177 \pm 26.9 \mathrm{~b}$ & $19.8 \pm 2.0 \mathrm{ab}$ \\
\hline & $25: 75$ & $181 \pm 38 \mathrm{c}$ & 0.24 & $41.8 \pm 0.7$ & $2.1 \pm 0.0 \mathrm{ab}$ & $76 \pm 15.5 c$ & $20.0 \pm 0.6 \mathrm{ab}$ \\
\hline & $0: 100$ & - & - & - & - & - & - \\
\hline \multirow{5}{*}{2017} & $100: 0$ & $1039 \pm 53 \mathrm{a}$ & 1.00 & $41.3 \pm 0.8$ & $2.4 \pm 0.0$ & $429 \pm 29.6 \mathrm{a}$ & $16.8 \pm 0.2$ \\
\hline & $75: 25$ & $811 \pm 39$ b & 0.78 & $42.0 \pm 0.7$ & $2.5 \pm 0.1$ & $341 \pm 20.5 \mathrm{ab}$ & $16.9 \pm 0.5$ \\
\hline & $50: 50$ & $611 \pm 44 \mathrm{c}$ & 0.59 & $42.4 \pm 0.7$ & $2.5 \pm 0.1$ & $260 \pm 23.1 \mathrm{~b}$ & $17.0 \pm 0.5$ \\
\hline & $25: 75$ & $321 \pm 32 \mathrm{~d}$ & 0.31 & $42.1 \pm 0.7$ & $2.3 \pm 0.1$ & $135 \pm 13.4 \mathrm{c}$ & $18.0 \pm 0.6$ \\
\hline & $0: 100$ & - & - & - & - & - & - \\
\hline
\end{tabular}

注 1）Tukey-Kramer 法による多重検定により各年データの同一の英添字間には $p<0.05$ で有意差がない.

注 2） $100 ： 0,75: 25,50 ： 50,25 ： 75,0 ： 100$ はギニアグラスとクロタラリアの標準播種量を 100 としたときのギニアグラス：クロタラリアの相対播種量である.

注 3) $R Y_{G}$ はギニアグラス単作区に対しての相対収量である.

年では旬別にみても平年值よりも低いか同等の 降水量であったが， 7 月上旬では平年值の 2 倍 以上の降水が見られた。生育期間中の積算気温 は 2016 年では $1419.8^{\circ} \mathrm{C}, 2017$ 年では $1719.6^{\circ} \mathrm{C}$ と 2017 年で高かった。また, 両年ともに平年值と 概ね同等の気温であった。

カバークロップのバイオマスおよび吸収養分は 混作割合によって大きく異なった（表 1 , 表 2 ).
混作により, 単作にくらべて両カバークロップと もにバイオマスが減少した，2016 年はクロタラ リアで相対収量が $75: 25$ 区で $0.17,50: 50$ 区で $0.27,25: 75$ 区で 0.53 となった。 2017 年はギニ アグラスの相対収量は全ての混作区において播種 比率に対して 3-5\%増加した。これに対し, クロ タラリアの相対収量は全ての混作区において播種 比率に対して 1-2\%低下した。 
表 2 クロタラリアのバイオマス及び成分 (2016 年 8 月, 2017 年 9 月)

\begin{tabular}{|c|c|c|c|c|c|c|c|}
\hline \multirow{2}{*}{\multicolumn{2}{|c|}{ 処理区 }} & \multicolumn{6}{|c|}{ クロタラリア地上部 } \\
\hline & & $\begin{array}{c}\text { バイオマス } \\
\text { (DW-kg/10 a) }\end{array}$ & $R Y_{C}$ & $\begin{array}{c}\mathrm{C} \text { 含有率 } \\
(\%)\end{array}$ & $\begin{array}{c}\mathrm{N} \text { 含有率 } \\
(\%)\end{array}$ & $\begin{array}{l}\text { C 含有量 } \\
(\mathrm{kg} / 10 \mathrm{a})\end{array}$ & $\mathrm{C} / \mathrm{N}$ 比 \\
\hline \multirow{5}{*}{2016} & $100: 0$ & - & - & - & - & - & - \\
\hline & $75: 25$ & $57 \pm 10 \mathrm{~b}$ & 0.17 & $43.2 \pm 0.6$ & $3.6 \pm 0.2$ & $24 \pm 4.1 \quad b$ & $12.1 \pm 0.8$ \\
\hline & $50: 50$ & $91 \pm 5 \quad b$ & 0.27 & $43.2 \pm 0.3$ & $3.2 \pm 0.2$ & $39 \pm 2.3 \quad b$ & $13.6 \pm 1.0$ \\
\hline & $25: 75$ & $179 \pm 34 b$ & 0.53 & $44.2 \pm 0.4$ & $3.0 \pm 0.2$ & $79 \pm 15.3 \mathrm{~b}$ & $15.1 \pm 0.8$ \\
\hline & $0: 100$ & $340 \pm 56 \mathrm{a}$ & 1.00 & $44.6 \pm 0.3$ & $3.0 \pm 0.1$ & $152 \pm 25.7 \mathrm{a}$ & $14.7 \pm 0.6$ \\
\hline \multirow{5}{*}{2017} & $100: 0$ & - & - & - & - & - & - \\
\hline & $75: 25$ & $180 \pm 28 d$ & 0.24 & $44.2 \pm 0.6$ & $2.7 \pm 0.0 \mathrm{a}$ & $80 \pm 12.9 c$ & $16.4 \pm 0.4 \mathrm{~b}$ \\
\hline & $50: 50$ & $357 \pm 11 \mathrm{c}$ & 0.48 & $44.2 \pm 0.9$ & $2.5 \pm 0.0 \mathrm{~b}$ & $158 \pm 7.7 \quad \mathrm{c}$ & $17.4 \pm 0.4 \mathrm{~b}$ \\
\hline & $25: 75$ & $543 \pm 19 b$ & 0.73 & $44.0 \pm 0.7$ & $2.4 \pm 0.0 \mathrm{~b}$ & $239 \pm 11.3 b$ & $18.1 \pm 0.2 \mathrm{~b}$ \\
\hline & $0: 100$ & $743 \pm 69 \mathrm{a}$ & 1.00 & $44.8 \pm 0.8$ & $2.3 \pm 0.0 \mathrm{c}$ & $332 \pm 29.5 \mathrm{a}$ & $19.9 \pm 0.4 \mathrm{a}$ \\
\hline
\end{tabular}

注 1）Tukey-Kramer 法による多重検定により各年データの同一の英添字間には $p<0.05$ で有意差がない.

注 2) $100 ： 0,75: 25,50 ： 50,25 ： 75,0 ： 100$ はギニアグラスとクロタラリアの標準播種量を 100 と したときのギニアグラス：クロタラリアの相対播種量である.

注 3) $R Y_{C}$ はクロタラリア単作区に対しての相対収量である.

表 3 カバークロップの合計地上部バイオマス及び成分 (2016 年 8 月, 2017 年 9 月)

\begin{tabular}{|c|c|c|c|c|c|}
\hline \multirow{2}{*}{\multicolumn{2}{|c|}{ 処理区 }} & \multicolumn{4}{|c|}{ カバークロップ地上部合計 } \\
\hline & & $\begin{array}{c}\text { バイオマス } \\
\text { (DW-kg/10 a) }\end{array}$ & $R Y_{T}$ & $\begin{array}{l}\text { C 含有量 } \\
(\mathrm{kg} / 10 \mathrm{a})\end{array}$ & $\mathrm{C} / \mathrm{N}$ 比 \\
\hline \multirow{5}{*}{2016} & $100: 0$ & $763 \pm 39$ a & - & $327 \pm 17 \mathrm{a}$ & $23.7 \pm 0.6 \mathrm{a}$ \\
\hline & $75: 25$ & $540 \pm 55 \mathrm{ab}$ & 0.80 & $231 \pm 24 \mathrm{ab}$ & $16.3 \pm 0.6 \mathrm{~b}$ \\
\hline & $50: 50$ & $501 \pm 63 \mathrm{~b}$ & 0.81 & $216 \pm 28 b$ & $18.3 \pm 1.8 \mathrm{~b}$ \\
\hline & $25: 75$ & $360 \pm 31 b$ & 0.76 & $155 \pm 14 \mathrm{~b}$ & $17.2 \pm 0.5 \mathrm{~b}$ \\
\hline & $0: 100$ & $340 \pm 56 \mathrm{~b}$ & - & $152 \pm 26 \mathrm{~b}$ & $14.7 \pm 0.6 \mathrm{~b}$ \\
\hline \multirow{5}{*}{2017} & $100: 0$ & $1039 \pm 53 \mathrm{a}$ & - & $429 \pm 30$ & $16.8 \pm 0.2 \mathrm{~b}$ \\
\hline & $75: 25$ & $991 \pm 39 \mathrm{a}$ & 1.02 & $421 \pm 23$ & $16.8 \pm 0.3 \mathrm{~b}$ \\
\hline & $50: 50$ & $968 \pm 55 \mathrm{ab}$ & 1.07 & $418 \pm 31$ & $17.1 \pm 0.4 \mathrm{~b}$ \\
\hline & $25: 75$ & $864 \pm 13 a b$ & 1.04 & $374 \pm 7$ & $18.0 \pm 0.3 \mathrm{~b}$ \\
\hline & $0: 100$ & $743 \pm 69 \mathrm{~b}$ & - & $332 \pm 30$ & $19.9 \pm 0.4 \mathrm{a}$ \\
\hline
\end{tabular}

注 1）Tukey-Kramer 法による多重検定により各年データの同一の英添字間には $p<0.05$ で有意差がない.

注 2) $100: 0,75: 25,50: 50,25: 75,0: 100$ はギニアグラスとクロタラリア の標準播種量を 100 としたときのギニアグラス：クロタラリアの相対播種量 である。

注 3) $R Y_{T}$ は合計相対収量であり, $R Y_{G}$ と $R Y_{C}$ の和である.

また，カバークロップの地上部バイオマスの 合計（イネ科とマメ科の合計）では，2016年は ギニアグラス単作区で 763 DW-kg/10 a となり, $50: 50$ 区, 25:75区, クロタラリア単作区と比
ベ有意に高かった（表 3). 2017 年ではギニアグ ラス単作区と $75: 25$ 区でクロタラリア単作区と 比べ有意に高い地上部バイオマスとなった．クロ タラリア単作区は両年を通じて最も低かった。 

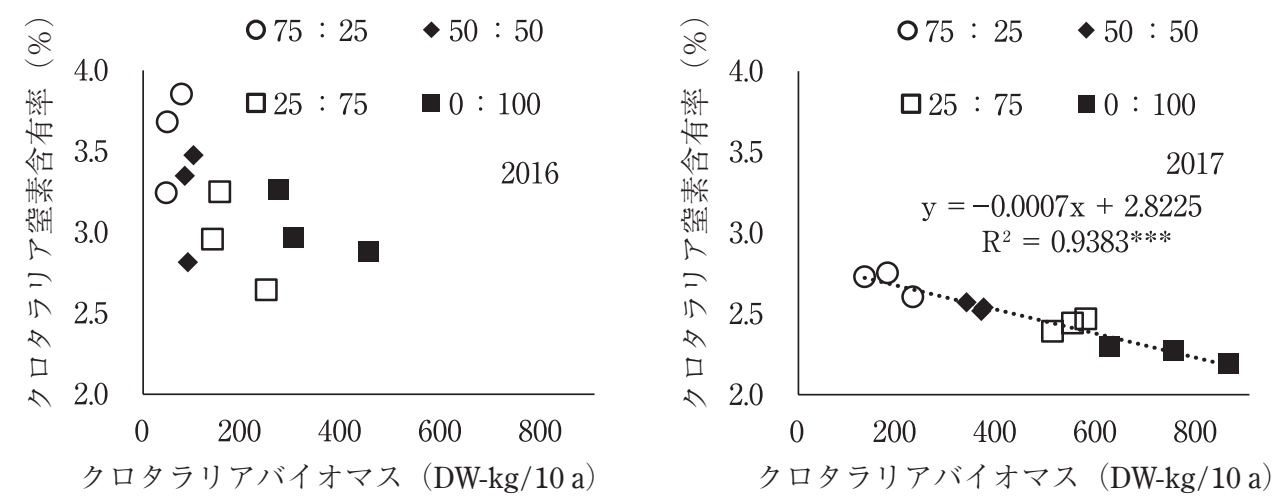

図 2 クロタラリア窒素含有率とクロタラリアバイオマスとの相関（2016 年 8 月, 2017 年 9 月）

注 1）***は は $p<0.001$ であることを示す.

注 2) $75 ： 25,50 ： 50,25 ： 75,0 ： 100$ はギニアグラスとクロタラリアの標準播種量を 100 とし たときのギニアグラス：クロタラリアの相対播種量である。

ロギニアグラス ロクロタラリア 田雑草

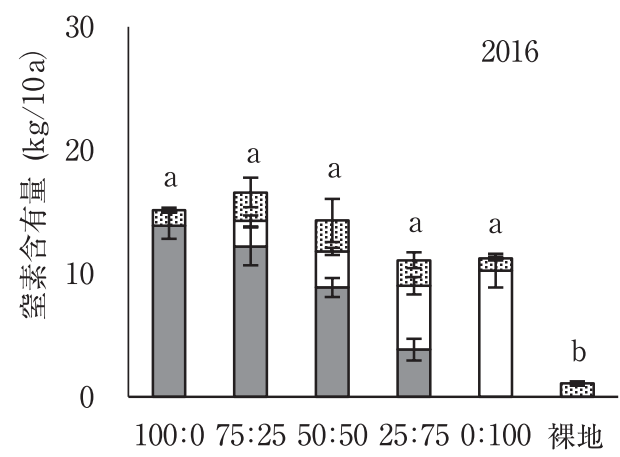

ロギニアグラス ロクロタラリア

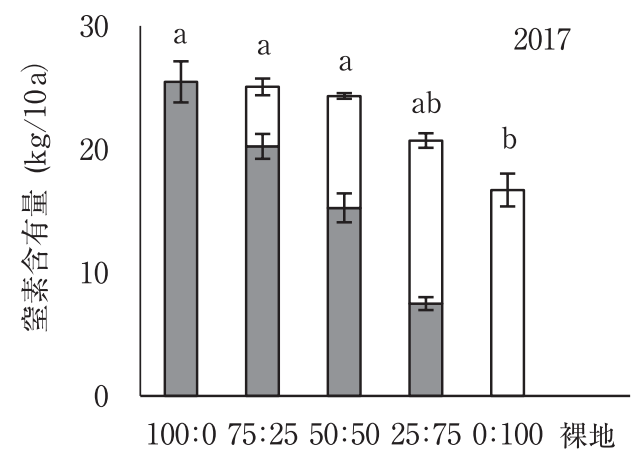

図 3 カバークロップの窒素含有量（2016 年 8 月, 2017 年 9 月)

注 1）Tukey-Kramer 法による多重検定により図中の同の英添字間において $5 \%$ 水準で有意差がない ことを示す。グラフ中の縦棒は標準誤差を示す.

注 2) $100 ： 0,75 ： 25,50 ： 50,25 ： 75,0 ： 100$ はギニアグラスとクロタラリアの標準播種量を 100 としたときのギニアグラス：クロタラリアの相対播種量である.

2）カバークロップの窒素含有率と $\mathrm{C} / \mathrm{N}$ 比

カバークロップの窒素含有率では, 2016 年の ギニアグラスに扔いて $75: 25$ 区でギニアグラス 単作区より高かった（表 1$)$. クロタラリアでは 混作により窒素含有率が増加する傾向が認められ た（表 2). 2017 年のクロタラリアで $75: 25$ 区に おいて窒素含有率は $2.7 \%$ とその他の処理区より も高かった。 とくにクロタラリアの播種比率が高 いほど窒素含有率が低かった（図 2)。ギニアグ ラスでは播種比率と窒素含有率の間に相関関係は 認められなかった。

カバークロップの $\mathrm{C} / \mathrm{N}$ 比は, 2016 年ではギニ
アグラス単作区で 23.7 と最も高かった（表 1 ) これに対し，クロタラリアでは処理区による有意 差はみられなかった（表 2)。また, 2017 年はク ロタラリア単作区で 19.9 とその他の区よりも高 い值を示したが，ギニアグラスでは処理区による 有意差はみられなかった。 ギニアグラス単作区の $\mathrm{C} / \mathrm{N}$ 比は 2016 年では $23.7,2017$ 年では 16.8 と 年次間で 6.9 の差 $(p<0.001)$ があった. 一方, クロタラリア単作区は 2016 年では $14.7,2017$ 年 では 19.9 と年次間で 5.2 の差 $(p<0.01)$ がみら れた。 カバークロップ地上部合計の $\mathrm{C} / \mathrm{N}$ 比を処 理間で比較すると, 2016 年のギニアグラス単作 
土壤硝酸態窒素態濃度 $(\mathrm{mg} / \mathrm{kg})$

$\begin{array}{lllllll}0 & 20 & 40 & 60 & 80 & 100 & 120\end{array}$

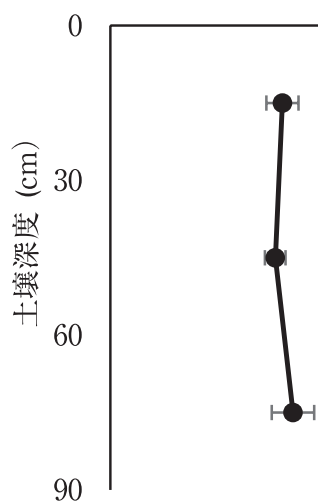

土畩硝酸態窒素態濃度 $(\mathrm{mg} / \mathrm{kg})$

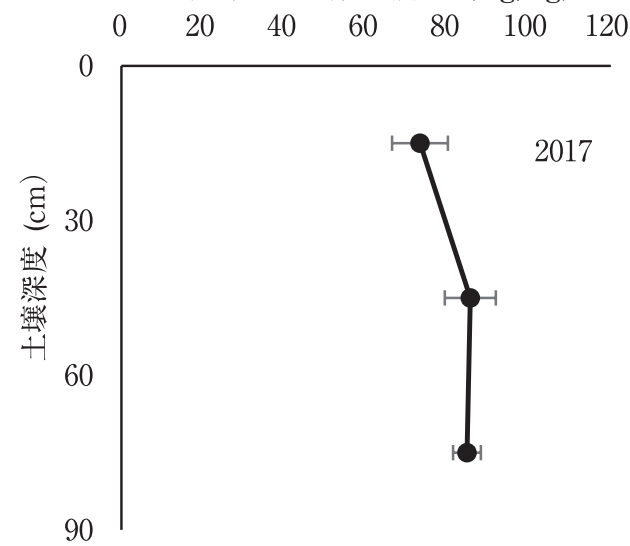

図 4 カバークロップ播種期における 0-90 cm 層の土壤硝酸態窒素濃度（2016 年 6 月, 2017 年 7 月） 注）グラフ中の横棒は標準誤差を示す.

土壤硝酸態窒素濃度 $(\mathrm{mg} / \mathrm{kg})$

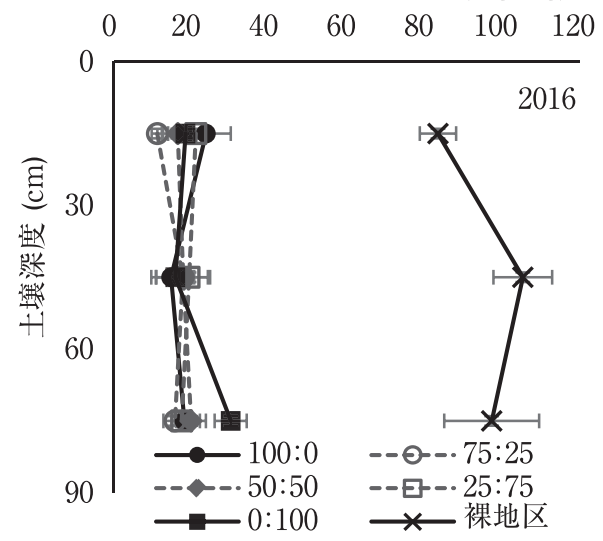

土袞硝酸態窒素濃度 $(\mathrm{mg} / \mathrm{kg})$

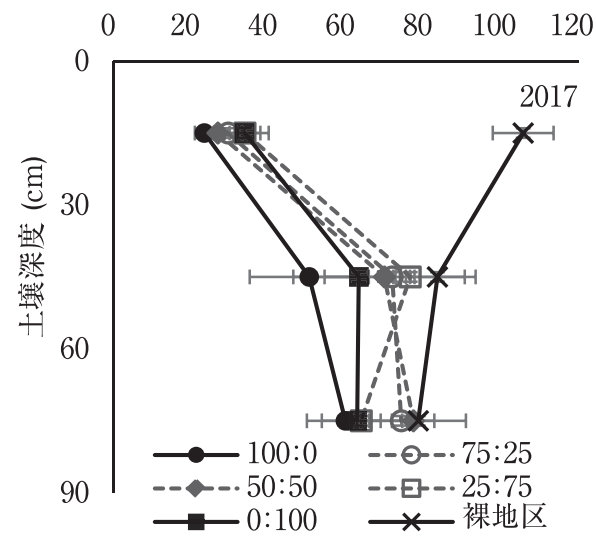

図 5 カバークロップX川取期における 0-90 cm 層の土壇硝酸態窒素濃度（2016 年 8 月，2017 年 9 月） 注 1) グラフ中の横棒は標準誤差を示す.

注 2) $100 ： 0,75: 25,50 ： 50,25 ： 75,0 ： 100$ はギニアグラスとクロタラリアの標準播種量を 100 としたときのギニアグラス：クロタラリアの相対播種量である.

区（23.7）ではその他の処理区よりも有意に高い 值となった（表 3). 2017 年ではクロタラリア単 作区が 19.9 とその他の処理区より有意に高い值 を示した。このように単作では $\mathrm{C} / \mathrm{N}$ 比が年次間 において大きく変動したのに対し，混作区では 2 年間を通じて処理間での差は小さく，16.3-18.3 の值を示した.

3）地上部窒素含有量

地上部窒素含有量は地上部バイオマスや播種量 に大きく影響された（図 3).2016 年はカバーク
ロップ作付区では裸地に比べて有意な差がみられ たが，カバークロップの処理間での差はみられな かった． 2017 年でクロタラリア単作区と比べて ギニアグラス単作区，75：25 区および50：50 区 で有意に高い值を示した。

\section{4）土㩙無機態窒素}

播種期の土壤硝酸態窒素濃度は, 2016 年と 2017 年で年次間差がみられ 2017 年が高かった(図 4). 層位別にみると 2016 年では 40-45 mg/ $\mathrm{kg}$, 2017 年では 73-85 mg/kg の範囲であり層位別に 
よる差は特にみられなかった。

土壤アンモニア態窒素についてはサンプリング 時期によって差がみられ刈取期よりも播種期が高 かったが，処理間での差異はなかった（デー夕省 略)。刚取期の土壤硝酸態窒素濃度では, 2016 年 は 0-90 cm 層において, 裸地区でカバークロッ プ作付区より有意に硝酸態窒素濃度が高かった (図 5). 2017 年では 0-30 cm 層で, カバークロッ プ作付区と比べ裸地区で硝酸態窒素濃度が高かっ た。しかし，30-90 cm 層ではいずれの処理区で も差はなかった。

\section{4. 考察}

夏作カバークロップが耕地環境において最も期 待される効果は有機物供給能力であるが (Magdoff 2004), カバークロップのバイオマスは天候条件な どにより大きく異なる (Komatsuzaki and Wagger 2015)。今回の試験では, カバークロップのバイ オマスは 2016 年より 2017 年が高かった。両年の 生育期間中の積算降水量㧍よび積算気温も 2016 年より 2017 年が高くなり，このことがバイオマ ス生産に影響したものと考える。また，両年に おいて播種方法も異なっていたことも考慮する必 要がある.

2016 年と 2017 年の合計相対収量を比較すると 2016 年では $0.76-0.80$ に対し 2017 年では $1.02-$ 1.07 を示している（表 3). 2017 年において，そ れぞれの草種に扔ける相対収量が向上した要因と しては条播による影響が考えられる。ギニアグラ スとクロタラリアの生育速度をみると, 2016 年 と 2017 年ともに播種後 40-50 日までの草高はク ロタラリアが先行し，その後はギニアグラスの生 育が旺盛となりクロタラリアを追い越していた (デー夕省略)。このような生育速度の差異は条播 と散播の条件下でも生じたものと考えられる。特 に条播であると杂隹草防除が容易に行えるのに対し 散播では防除を行うことができず，雑草の混入が 確認された。このような雑草の侵入によってもそ れぞれの相対収量の差異に影響を及ぼしたものと 考える.

本研究では, 夏作カバークロップの窒素含有率 が単作掞よび混作により大きく異なった点が注目 される。 さらに，カバークロップの分解特性とし て C/N 比をみると, 2016 年ではギニアグラス単 作区が最も高かったのに対し，2017 年ではクロ
タラリア単作区が最も高かった。 ギニアグラス単 作区の $\mathrm{C} / \mathrm{N}$ 比は 2017 年のほうが 2016 年に比べ 6.9 低くなっていた。播種期の土壤硝酸態窒素濃 度では, 2017 年は 0-30 cm で $73 \mathrm{mg} / \mathrm{kg}$ と 2016 年よりも $30 \mathrm{mg} / \mathrm{kg}$ 以上高い濃度であった。こ のことがギニアグラスの $\mathrm{C} / \mathrm{N}$ 比に影響した可能 性がある。一方でクロタラリア単作区の C/N 比 は 2017 年で 2016 年よりも 5.2 高くなった。この ようなクロタラリアの $\mathrm{C} / \mathrm{N}$ 比の年次間差は生育 期間や降水によって影響を受けるとする糟谷ら （2010）の報告と同様であった。マメ科に扔ける 窒素含有量は窒素吸収量と根粒菌による窒素固定 量がある. クロタラリアの窒素含有率は 2016 年 と比べて 2017 年で $0.7 \%$ 低くなっていたことや 播種期の硝酸態窒素濃度の違いがあったことから も窒素吸収量や窒素固定量に年次間で差があった 可能性がある，今後，これらについても検討する 必要がある。このように, 単作条件下では個々の カバークロップの $\mathrm{C} / \mathrm{N}$ 比が年次間において大き く変化したのに対し, 混作区の $\mathrm{C} / \mathrm{N}$ 比は年次間 において大きな差はなかった。このことは, 単作 よりも混作のほうが安定した C/N 比のカバーク ロップを提供できる可能性があり, 今後さらに検 討する必要がある.

カバークロップの環境保全機能として, 窒素溶 脱防止効果が大きい。これは, カバークロップの 窒素吸収により, 土䁃中の硝酸態窒素濃度が減少 するためである。 2016 年では 0-90 cm で低い硝 酸態窒素濃度を示し溶脱が抑制されたが，2017 年では 30-90 cm で裸地区とは差が見られなかっ た。これは 2016 年と 2017 年の降水・気温パター ンの差異の影響が考えられる.とくに, 2017 年 は播種直後の 7 月上旬に全降水量の約 $47 \%$ の降 雨が集中して降って抢り, カバークロップの生育 が小さい時期のため硝酸態窒素の溶脱が生じた可 能性が高い.そのため溶脱した硝酸態窒素が 9 月 の硝酸態窒素濃度に反映したと考える。しかし， 刈取後の 0-30 cm では両年ともに裸地区よりも カバークロップ作付区で硝酸態窒素濃度が低下し 溶脱が抑制されたものと考える.

夏作カバークロップの混作のメリットを考えて みると, 気候条件, 播種条件や耕地環境などが変 化する中で, イネ科拈よびマメ科のカバークロッ プを混作することで, バイオマス生産や養分吸収 が安定する傾向が認められた点は興味深い.とく 
に，イネ科カバークロップが高い $\mathrm{C} / \mathrm{N}$ 比を示し てもマメ科がそれを低減し, 地上部合計 $\mathrm{C} / \mathrm{N}$ 比 を改善することが認められる等，土壤の肥培管理 的なメリットが大きい.

夏作カバークロップは植物体として前作の残留 養分を吸収し圃場に養分を保持することからも夏 作作物の休閑期間への導入や秋 · 冬作作物の生産 に寄与することが期待される，特に多肥傾向にあ る野菜生産の現場では夏作カバークロップの利用 は作物生産と環境負荷軽減に大きく貢献できる。 また, 地球温暖化に伴う近年の異常気象の頻発は 今までとは異なる気候パターンを生じ, 作物生産 体制を不安定化させる要因となっている。この中 でカバークロップによる硝酸態窒素の溶脱抑制は 単作と同等の効果が混作でも認められた。 特にイ ネ科のギニアグラスは気候条件や围場の窒素条件 に左右されやすいが, マメ科のクロタラリアと混 作することによりバイオマス生産能の維持と C/ $\mathrm{N}$ 比改善など安定的なカバークロップ利用を可能 とすることが期待される.

\section{謝辞}

本研究の遂行に当たり, 国立研究開発法人農業. 食品産業技術総合研究機構農業環境変動研究セン ターの荒城雅昭氏およびカネコ種苗株式会社の西 本淳氏並びに茨城大学農学部の岡山毅氏に多大な るご協力を頂いた。ここに記して感謝の意を表す.

\section{引用文献}

Abdul-Baki A A, Morse R D, Teasdale J R and Devine T E (1997) : Nitrogen requirements of broccoli in cover crop mulches and clean cultivation, Journal of Vegetable Crop Production $3(2)$; 85-100.

Asagi N and Ueno H (2009) : Nitrogen dynamics in paddy soil applied with various ${ }^{15} \mathrm{~N}$-labelled green manures, Plant and Soil $322 ; 251-262$.

大門弘幸 (2017)：緑肥作物の栽培と利用, 牧草と 園芸 $65(3) ； 1-6$.

平田聡之 ·野口大輔 · 荒木 肇 (2017) : 北海道 道央部の 2 つの春コムギ栽培体系における ヘアリーベッチ導入による窒素肥料の削減, 農作業研究 52 (3)；133-142.

Holderbaum J F, Decker A M, Meisinger J J, Mulford F R and Vough L R (1990) : Fall-seeded legume cover crops for no-tillage corn in the humid east, Agronomy Journal $82(1)$; 117 124.

糟谷真宏・廣戸誠一郎（2010）：秋冬キャベツ栽 培の夏季休閑期への緑肥作物導入による窒素 収支の改善, 愛知農総試研報 $42 ; 141-146$.

北上 達·大久保憲秀・山本敏夫 (1992)：クロ タラリア・スペクタビリスによるサッマイモ ネコブセンチュウ制御技術, 関西病虫害研究 会報 $34 ； 33-34$.

気象庁 (2017) : 茨城県土浦アメダスデータ, http://www.data.jma.go.jp/obd/stats/etrn/ index.php?prec_no $=40 \&$ block_no $=0324 \&$ year $=\&$ month $=\&$ day $=\& v i e w=.(2018$ 年 2 月 6 日 閲覧).

Komatsuzaki M. (2002) : New cropping strategy to reduce chemical fertilizer application to silage corn production using subterranean clover reseeding, Japanese Journal of Farm Work Research 37 ; 1-11.

小松㟝将一 (2004): 畑作でのカバークロップ利用, 農作業研究 39 (3)；157-163.

小松崎将一 (2009)：黒ボク土壤水田での裏作カ バークロップの窒素吸収量と土壤窒素の動 態, 農作業研究 44(4)；201-210.

Komatsuzaki M and Wagger M G（2015）：Nitrogen recovery by cover crops in relation to time of planting and growth termination, Journal of Soil and Water Conservation 70 (6) ; 385-398.

Kuo S, Sainju U M and Jellun E (1996) : Winter cover cropping influence on nitrogen mineralization, presidedress soil nitrate test, and corn yields, Biology and Fertility of Soils 22 (4) ; 310-317.

水久保隆之 (2005) : 対抗植物, 天敵微生物等を 利用した線虫防除技術, https://www.naro.affrc. go.jp/training/files/2005_1-06.pdf.（2017 年 11月 10 日閲覧).

Magdoff F, Weil R R (2004) : Soil organic matter in sustainable agriculture, CRC press, Boca Raton, Florida.

農林水産省（2017）：環境保全型農業直接支払交付 金 平成 28 年度実施状況, http://www.maff. go.jp/j/seisan/kankyo/kakyou_chokubarai/ mainp.html（2017 年 10 月 22 日閲覧）。 
小川吉雄（2000）：地下水の硝酸污染と農法転換

- 流出機構の解析と窒素循環の再生, 農山漁 村文化協会.

大橋 哲・俣野 修 (2003)：黑ボク土野菜畑に おける牛ふんおがくず堆肥および被覆肥料由 来窒素の溶脱，日本土壤肥料学雑誌 74(5); 631-635.

大林延夫・森東海雄（1989）：ギニアグラス及び マリーゴールドの栽培によるキタネグサレセ ンチュウの防除効果, 関東東山病害虫研究会 年報 $36 ； 204-206$.

Rasmussen J, Eriksen J, Jensen E S, Esbensen, K $\mathrm{H}$ and Hogh-Jensen H (2007) : In situ carbon and nitrogen dynamics in ryegrass-clover mixtures: Transfers, deposition and leaching, Soil Biology and Biochemistry 39 (3) ; 804-815.

Sainju U M, Singh B P and Whitehead W F (1998) : Cover crop root distribution and its effects on soil nitrogen cycling, Agronomy Journal 90 ; 511-518.

Sugihara Y, Ueno H, Hirata T and Araki H (2013) : Uptake and distribution of nitrogen derived from hairy vetch used as cover crop by tomato plant, Journal of the Japanese Society for Horticultural Science 82 (1) ; 30-38.

Sugihara Y, Ueno H, Hirata T, Komatsuzaki M and Araki H (2016) : Contribution of N Derived from a Hairy Vetch Incorporated in the Previous Year to Tomato N Uptake under Hairy Vetch-tomato Rotational Cropping System, The Horticulture Journal, 85 (3)；217-223.

樽井 新・松村 篤・大門弘幸 (2011)：ヘアリー ベッチとエンバクの混作に扔ける養分動態と 後作トゥモロコシへの緑肥効果, 第 232 回日 本作物学会講演会 P 82 .

Xiao Y, Li L and Zhang F (2004) : Effect of root contact on interspecific competition and $\mathrm{N}$ transfer between wheat and fababean using direct and indirect $15 \mathrm{~N}$ techniques, Plant Soil $262 ; 45-54$.

\section{Abstract}

Gramineae and Leguminosae are used as summer cover crops in monoculture; however, their biculture system has not been studied well. This study compared the effects of biculture of summer cover crops on biomass production and nitrogen leaching in the fields of the Field Science Education Center, Ibaraki University. The fields were seeded using different seeding ratios of guinea grass (Panicum maximum Jacq. cv. Natsukaze) and crotalaria (Crotalaria spectabilis Roth. cv. Nemaclean). We prepared six combinations of the biculture in the following seeding ratios: 100:0 (guinea grass monoculture), 75:25, 50:50, 25:75, 0:100 (crotalaria monoculture), and 0:0 (bare). In 2016, the aboveground biomass of the cover crop, the $\mathrm{C} / \mathrm{N}$ ratio, and the amount of absorbed carbon were highest in the harvested guinea grass monoculture crop compared with the other seeding ratios. In 2017, the aboveground biomass in the guinea grass monoculture crop and in the 75:25 biculture crops were almost similar, while it was lowest for crotalaria monoculture crop. On the other hand, the $\mathrm{C} / \mathrm{N}$ ratio was the highest in the crotalaria monoculture crop. The concentration of nitrate in the soil decreased significantly due to the cover crop uptake in the both years. The results of these two years showed that it is possible to increase the decomposability of the residue and promote the supply of organic matter necessary for agricultural productivity of the land, securing biomass production, by lowering the $\mathrm{C} / \mathrm{N}$ ratio.

\section{Key Words}

biculture, crotalaria, guinea grass, nitrogen reaching 